\title{
THE IMPACT OF ISLAMIC WORK ETHICS ON JOB SATISFACTION, ORGANIZATIONAL COMMITMENT AND WORK PERFORMANCE
}

\author{
Aamir Kibria \\ Lecturer, University of Sufism and Modern Sciences, Department of Management Sciences, \\ Sindh, Pakistan
}

Ikramuddin Junejo*

Faculty of SZABIST Hyderabad Campus, Department of Management Sciences,

Hyderabad, Pakistan

\section{Mehtab Siddique}

Assistant Professor, Institute of Commerce, University of Sindh, Jamshoro, Pakistan

\section{Dr. Ashfaque Ali Banbhan}

Assistant Professor, Institute of Commerce, University of Sindh, Jamshoro, Pakistan

*Corresponding Author

\begin{abstract}
This research measures association of Islamic work ethics (IWE) with employees' job satisfaction, organizational commitment and work performance in perspective of private sector organizations of Pakistan. Entire data collected via survey questionnaire from senior management to first line managers. In order to carry out this investigation, the participants which were targeted for data collection were quite familiar to and practice IWE at work. PLS SEM practices were applied on 228 cases for testing of hypotheses formulated in conceptual model. The findings demonstrate IWE as major predictor of satisfaction, commitment and performance. Employees practicing IWE seemed to have stability and longevity with the organization which indicates lesser employee quitting. Furthermore, hypothetical and managerial implications of the study are discussed.
\end{abstract}

Key words: Islamic Work Ethics, Job Satisfaction, Organizational Commitment, Work Performance. 
Cite this Article: Aamir Kibria, Ikramuddin Junejo, Mehtab Siddique and Ashfaque Ali Banbhan, The Impact of Islamic Work Ethics on Job Satisfaction, Organizational Commitment and Work Performance, International Journal of Management (IJM), 11(12), 2020, pp. 3020-3027.

http://iaeme.com/Home/issue/IJM?Volume=11\&Issue $=12$

\section{INTRODUCTION}

The choices made by a person regarding what is incorrect and what is correct is the part of ethics, ethics is a combination of various moral values that help to identify that what is right and what is wrong (Suib and Said, 20170). One of the main reasons of failures of corporations and worries in public are because of unethical behaviors (Haroonet al., 2012). Generally, several researches have been conducted on Islamic work ethics in all over the world from nonMuslim countries and Muslim countries; but in the perspective of Pakistan, very limited research evidences have been found. As a result, this study addresses this research gap to contribute in literature in context of Pakistan.

The Islamic work ethic received incredible attention in the 1980s from Muslim scholars (Tufail et al., 2017). For example, Yousef, (2000), it is investigated the impact of the Islamic work ethic on the relationship between administrative behavior and employee satisfaction, and found a direct impact on the Islamic work ethic in terms of administrative commitment and work stress. It is stated that the influence of the Islamic work ethic on job satisfaction, commitment and growth of employee income is positive and solid. To understand the connection between work ethic and employee satisfaction, it is necessary to define ways to combine explanatory factors and strategies that reduce. As we know that Pakistan is the country which has variety of cultures, thus this is very much important to conduct study on this in context of Islamic work ethics, it has been overlooked by researchers to

Investigate the influence of Islamic work ethics on job satisfaction specifically in perspective of private sector organizations of Pakistan. In this research it has been tried to examine relationship among Islamic work ethics, organizational commitment, and employee satisfaction regarding job and employee work outcomes of private sector organizations in Pakistan (Tufailet al., 2017). Additionally, this research also tried to find out correlation and covariance among basic variables that how they impact on each other.

\section{EMPIRICAL STUDIES AND HYPOTHESIS DEVELOPMENT}

\subsection{Islamic Work Ethics and Employee Job Satisfaction}

Satisfaction of job influenced by various factors, these factors may be psychological, financial and social, employee wages, job security, promotion opportunities, intrinsic motivation, employee supervision, efficiency and management abilities, relationship among workers, quality of their life, career development relationship among supervisor and subordinates (Salin et al., 2017). He describes that organizations must focus on worker's satisfaction towards job, their performance and work outcomes and personal health of employee. The satisfaction of worker regarding job is not only concerned with employee life but it leaves impact on employee attitude and behavior, a good attitude of employee creates employee mutual understanding and develop team work abilities that lead towards enhancement in employee as well as organizational performance. Mohamed (2010), it is reported that many researchers have found a positive and significant link between work ethic and employee satisfaction. The same findings can also be found in studies (Osibanjoet al., 2018). In addition, previous studies also analyzed the impact of ethics on employee job satisfaction from a cultural and organizational perspective, leading a work ethic between senior management and supervisors, such as discussions on the ethics of the office, the feasibility of promises and commitments, and their development as an 
ethical model and employee satisfaction (Atharet al., 2016). It is reported that senior management that supported their ethical behavior in prestigious organizations has a positive impact on employee satisfaction. Of similar respondents, indicators of different work values may have different sound effects for job satisfaction. According to a study of 1,174 employees and managers, the own questioning had a negative impact on job satisfaction and other factors, such as the team's findings, social responsibility, regulation, legal and ethical standards, all with a positive impact on the work satisfaction.

H1: Islamic work ethics is positively and extensively related with employee job satisfaction.

\subsection{Islamic Work Ethics with Organizational Commitment}

The study described that commitment is a kind of intention or feeling that enforce particular individual accordingly to their particular task (Meyer and Herscovitch, 2001). The employee usually experiences three types of commitment force which are Affective, normative and continuous, which reflects the emotional ties, the perceived obligation and the observed reductions in costs in relation to the goal. In addition, they believe that any scale designed to measure organizational commitment should consider one of these ways of thinking and being an objective.

The research examines in depth the commitment of the organization with the perspective of the association or the Islamic work ethic when it examines the relationship between the Islamic work ethic and organizational change and commitment to the United Arab Emirates (Yousef, 2000). Respectively, investigated and recognized the link between the values of Islamic work and the employee's organizational commitment during a case study conducted by a local bank in Malaysia and this study, it was found that both were quite strongly connected (Rahmanet al., 2006).

H2: The Islamic work ethic is positively and significantly related to the commitment towards organization

\subsection{Islamic Work Ethics with Employee Performance}

The Koran has clear instructions for faithful commitment and commitment to work, and does not allow unethical behaviors such as begging, laziness, waste of time and remaining productivity, it is found that work is considered a mandatory IWE action to obtain legal income and succeed in a career (Salinet al., 2017). Islam considers ethics as the system of the Muslim faith of Eman and is manifested in the Islamic worldview of human life. Ethics is also called akhlak, which is a set of Islamic moral values, defined in principle in the Qur'an and by the Prophet Muhammad. (PBUH) has achieved during his life (McGee, 2012). It is reported that employee work performance can be defined as that how a particular employee is performing his duty in other words all the activities done by an employee regarding his work is all about the employee performance. Those organizations which follow ethical rules and regulation have more chances to achieve goals, employee accountability and communication effectiveness (Abdiet al., 2014). It is stated that Islamic work ethics inculcate employees to gain good working abilities, put more efforts, be competitive, loyal and behave appropriately (Aliet al., 2007).

$\mathbf{H}_{3}$ : Islamic work ethics is positively and significantly related with employee performance

\subsection{Employee Job Satisfaction with Organizational Commitment}

Organizational commitment and employee work satisfaction have been analyzed very deeply by several researchers by various disciplines for the reason that they have very crucial impact on organizations and individual behaviors (Ibrahim, 2017). It is also described the worthiness of their relations among each other that one cannot oversight basic determinants e.g. job 
satisfaction, commitment and performance and their relations. Various studies conducted in several professions founded significant relationships among job satisfaction with organizational commitment among restaurant workers and analysis proved that satisfaction leads towards commitment in employees

Research on Pakistani university teachers revealed that employee satisfaction towards their jobs created loyalty among employees and workers become more committed with job and organization (Chughtai, and Zafar, 2006). It is explored the relationship between Pakistan's professional development opportunities, work life policies, workplace characteristics, and the commitment of IT professionals to the organization. The results emphasized that career development and IT employment policies are highly correlated with employee engagement.

H4: Employee job satisfaction is positively and significantly related with organizational commitment.

\subsection{Employee Job Satisfaction with Employee Performance}

It is reported that association among job satisfaction has been importantly investigated in various organizations, and findings of those studies are mixed having different opinions. Studies identified some major points in concerning relationship, which were satisfaction creates employee performance, employee performance enhance satisfaction and rewards and recognitions develop both performance and job satisfaction these views are supported by various researchers. employee which are satisfied were less likely to show scarcity and they have more organizational commitment, his participants were bank employee which were performing job as a teller officers (Salinet al., 2017). It is found that there is a significant and positive relationship between job satisfaction and employee performance.

H5: Employee job satisfaction is positively and significantly related with employee performance

\subsection{Organizational Commitment with Employee Performance}

Consequently, we could say that organizational commitment is significantly associated with employee job satisfaction, it has been found in some previous studies that organizational commitment is not that much linked with employee job satisfaction There is a major link in organizational commitment and employee work satisfaction. Those employees which are committed with organization they have more satisfaction level with their job. This is about a psychological attachment of employee regarding their workplace (Sharmaet al., 2009).

It is stated in their research studies that those employees whom have very strong organizational commitment could result in decrease in turn over intentions as a result employee work better for the organization (Schuler and Jackson, 2008). The meta-analysis showed that the average correlation between the organization's commitment and the employees' performance contained zero, which had a direct impact on the performance of the employees.

H6: organizational commitment is positively and significantly associated with employee performance

\section{MATERIAL AND METHODS}

\subsection{Measure}

The data source of the study is 'Primary', which involves the collection of research data directly from the respondents. In other words, the primary source is the direct data source related to the subject or problem. Here, private educational Institutes of Sindh, Pakistan. 


\subsection{The Population of The Study}

The population of a research study is a general public that prefers cab services for their purpose of work. The population of the study consists of the private Institute of Pakistan.

\subsection{Sampling Strategy}

In the primary research, sampling is an important component, which determines the number of respondents participating in the research study. Due to several constraints, including time, geographic and finance, a study needs to select a subset of the population. The sampling process can be either probability or non-probability. In this case, the 'convenience sampling' technique is used, which is a form of non-probability sampling and considers accessibility and proximity of the respondents.

\subsection{Sample Size}

The most acceptable way of determining the sample is 10:1 (10 samples for one item. According to proposed a rule of thumb that in case of quantitative and Multiple Regression Analysis is good enough to sample size criteria as (number of items *10). In our case, the Total number item is $10^{*} 22=220$, with a response rate of 90 percent.

\section{RESULTS}

\subsection{Descriptive Results}

Table 1 shows the Cronbach's alpha and descriptive statistics of the pilot and final studies. The Cronbach's alpha of all variables of pilot and final study are greater than the considerable value of 0.7 , Composite reliability should be 0.7 or higher. In case of exploratory research, 0.6 or higher is acceptable. All variable showed strong internal consistency of items within the constructs likewise IWE 0.9273 , OC 0.8850 , JS 0.8419 and EP 0.8689 respectively. It has been also found that all items of their concerned variables having very much strong mean value along with dispersion likewise IWE having mean value of 6.15, OC 5.33, JS 5.54 and EP 5.91 which is very much above from the mid value of 3.5.

Table 1 Descriptive statistics and Cronbach's alpha

\begin{tabular}{|c|c|c|c|c|}
\hline Variable & Alpha Pilot Study & $\begin{array}{c}\text { Alpha } \\
\text { Final Study }\end{array}$ & Mean & Std Deviation \\
\hline Islamic Work Ethics & 0.794 & 0.9273 & 6.15 & 0.821 \\
\hline Organizational Commitment & 0.765 & 0.8850 & 5.33 & 1.342 \\
\hline Job satisfaction & 0.800 & 0.8419 & 5.54 & 1.171 \\
\hline Employee Performance & 0.780 & 0.8689 & 5.91 & 1.091 \\
\hline
\end{tabular}

\subsection{PLS Sem Results}

Smart PLS is a mile stone in latent variable modeling. It unites state of art techniques likewise PLS-POS, IPMA, Complex Bootstrapping routines with easy access and usability and graphical user boundary (Hairet al., 2012). The analyses and findings of this research are based on usage of PLS SEM statistical analysis approaches, for the reason that it provide better and advanced methods of investigating relationships among the variables, as (Henseleret al., 2015), said that SmartPLS added various new approaches particularly in perspective analyzing convergent and divergent validity of latent variables and it enhances research's ability to understand more structural patterns and measurement models, various analyses were done with the help of SmartPLS which are given as under. 
Table 2 presents the convergent validity; also called AVE average variance extracted and discriminate validity, Fornell and Larcker (1981) described that AVE value greater than 0.5 is considered good. Here all latent variables IWE, OC, JS and EP having strong AVE with the value of $0.5582,0.6379,0.6139$ and 0.6051 . Table 3 , also explored the divergent and $\mathrm{R}$ Square values which are now a day's quite important to investigate relationship among variables in the study. The evaluation of discrimination has become a generally accepted condition for analyzing the relationship between hidden variables. Divergent validity is a condition in which two theoretical relevant concepts are not relevant. Furthermore, it is reported that "discriminate validity as that it having motive to confirm that a reflective construct having a worthy association with his own items in PLS path model". Divergent and R Square values of all latent variables IWE, OC, JS and EP are quite strong with the values of 0.7471 with R Square value of $0.000,0.7986$ with R Square value of $0.9204,0.7835$ with R Square value of 0.9363 and 0.7778 with R Square value of 0.9892 respectively. Furthermore, Bagozzi and Yi, (1988) said that composite reliability should be 0.7 or greater in case of explanatory research. The Internal consistency reliability in other words composite reliability is very significant, all variable have robust compound dependability with the standards of 0.9378 IWE, $0.9132 \mathrm{OC}, 0.8880 \mathrm{JS}$ and 0.9017 of EP which is presentation that interior consistency indicators are stacking better to their own.

Table 2 Covariance and Internal Consistency of Constructs

\begin{tabular}{|l|c|c|c|c|}
\hline \multicolumn{1}{|c|}{ Variable } & AVE & Divergent & $\begin{array}{c}\text { Composite } \\
\text { Reliability }\end{array}$ & $\begin{array}{c}\text { Cronbach's } \\
\text { Alpha }\end{array}$ \\
\hline Islamic Work Ethics & 0.5582 & 0.7471 & 0.9378 & 0.9273 \\
\hline $\begin{array}{l}\text { Organizational } \\
\text { Commitment }\end{array}$ & 0.6379 & 0.7986 & 0.9132 & 0.8850 \\
\hline Job Satisfaction & 0.6139 & 0.7835 & 0.8880 & 0.8419 \\
\hline Employee Performance & 0.6051 & 0.7778 & 0.9017 & 0.8689 \\
\hline
\end{tabular}

\subsection{Hypothesis Testing}

In the next structural model of the Route Analysis Phase, we re-sampled 5,000 times (boot method) to get statistics and estimates of standard deviations of loads and route coefficients (Hair et al., 2010). 1.96 and 1.65 in the research study, the route factor is considered to be significant. In this study, Figure 2 and Table 3 show that all variables have a significant relationship between them. At this point IWE with value of 131.1776 is showing an extremely important relationship with JS and secondly Islamic Work Ethics (IWE) has fairly significant linkage with organizational commitment (OC) with the value of 2.5110. Similarly, IWE having very strong linkage with EP with value of 2.9368, job satisfaction JS strongly related with EP and OC with value of 14.065 and 5.5463 and lastly organizational commitment also is having significant relationship with EP with the value of 13.868 respectively.

Table 3 Path coefficient

\begin{tabular}{|c|c|c|c|}
\hline Variable & Beta & Standard Error & T Statistics \\
\hline IWE -> JS & 0.9676 & 0.0074 & 131.1776 \\
\hline IWE -> OC & 0.2956 & 0.1177 & 2.5110 \\
\hline IWE -> EPER & 0.1182 & 0.0403 & 2.9368 \\
\hline JS -> EPER & 0.5269 & 0.0410 & 14.0651 \\
\hline JS -> OC & 0.6704 & 0.1209 & 5.5463 \\
\hline OC -> EPER & 0.3115 & 0.0225 & 13.8687 \\
\hline
\end{tabular}




\section{CONCLUSION AND FUTURE DIRECTIONS}

The findings of current research suggested that due to ethics employee become more loyal and having good behavior at work place, employee become satisfied with their job and organization even at workplace they feel secure, they become more committed with their and for organization as a result employee want to stay in the organization. If organizations will adopt this approach regarding above factors, particularly Islamic employment ethics, these could enhance employee job satisfactory about job which will create organizational commitment among employees and it will lead towards decrease in employee turnover ratio, thus its suggested that it is very important for related management authorities that they should pay their attention towards it. Islamic work ethics is not only concerned with effort and task accomplishment, it also enhances and establish community relations because Islamic work upholds the work life equilibrium, it creates teamwork and light up the concept to work helpfully and collectively rather than distinctiveness. With consideration of this to construct teams and groups of workers which perform work jointly by enhancing their pledge level with the institute for enhancing job presentation of employee and carrying the fruitful and maintain able expansion in private sector organizations of Pakistan.

There is a huge limitation of literature, various studies regarding this are from Eastern developing countries, it is generally not realized in western and developed countries and specified on Muslim countries thus future research should focus on its realization of importance in various HR factors within the organization, Additionally research should investigate relationship among work ethics in Islamic perspective, job satisfaction, commitment and employee performance in other non-Islamic countries and in other religions and other countries like, Hindus, Buddhism. There could be some other implication of Islamic work ethics in various dimensions alike, Organizational Justice, Motivation of employees, performance, job security and others.

\section{REFERENCES}

[1] Abdi, M. F., Nor, S. F. D. W. M., \& Radzi, N. Z. M. (2014). The impact of Islamic work ethics on job performance and organizational commitment. In Proceedings of 5th Asia-Pacific Business Research Conference, Kuala Lumpur, Malaysia (pp. 1-12).

[2] Ali, A. J., \& Al-Kazemi, A. A. (2007). Islamic work ethic in Kuwait. Cross cultural management: An international Journal, 14(2), 93-104.

[3] Athar, M. R., Shahzad, K., Ahmad, J., \& Ijaz, M. S. (2016). Impact of islamic work ethics on organizational commitment: Mediating role of job satisfaction. Journal of Islamic Business and Management Vol, 6(1), 397-416.

[4] Chughtai, A. A., \& Zafar, S. (2006). Antecedents and consequences of organizational commitment among Pakistani university teachers. Applied H.R.M. Research, 11(1), 39-64.

[5] Hair, J. F., Sarstedt, M., Ringle, C. M., \& Mena, J. A. (2012). An assessment of the use of partial least squares structural equation modeling in marketing research. Journal of the academy of marketing science, 40(3), 414-433.

[6] Haroon, M., Zaman, H. F., \& Rehman, W. (2012). The relationship between Islamic work ethics and job satisfaction in healthcare sector of Pakistan. International Journal of Contemporary Business Studies, 3(5), 6-12. 
[7] Henseler, J., Ringle, C. M., \&Sarstedt, M. (2015). A new criterion for assessing discriminant validity in variance-based structural equation modeling. Journal of the academy of marketing science, 43(1), 115-135.

[8] Ibrahim, A. (2017). The commitment to Islamic work ethics among Islamic banking employees in Aceh. Jurnal Syariah, 24(1).

[9] McGee, R. W. (2012). The ethics of tax evasion in Islam: a comment. In The Ethics of Tax Evasion (pp. 159-165). Springer, New York, NY

[10] Meyer, J. P., \& Herscovitch, L. (2001). Commitment in the workplace: Toward a general model. Human resource management review, 11(3), 299-326.

[11] Mohamed, N., Karim, N. S. A., \& Hussein, R. (2010). Linking Islamic work ethic to computer use ethics, job satisfaction and organisational commitment in Malaysia. Journal of Business Systems, Governance and Ethics, 5(1), 13-23.

[12] Osibanjo, A. O., Akinbode, J., Falola, H. O., \& Oludayo, O. O. (2018). Work ethics and employees' job performance. Journal of Leadership, Accountability and Ethics, 12(1), 107-117.

[13] Rahman, N. M., Muhamad, N., \& Othman, A. S. (2006). The relationship between Islamic work ethics and organizational commitment: A case analysis. Malaysian Management Review, 41(1), 79-89.

[14] Salin, A. S. A. P., Ab Manan, S. K., Kamaluddin, N., \& Nawawi, A. (2017). The role of Islamic ethics to prevent corporate fraud. International Journal of Business and Society, 18(S1), 113128.

[15] Schuler, R. S., \& Jackson, S. E. (2008). Strategic human resource management. John Wiley \& Sons.

[16] Sharma, D., Borna, S., \& Stearns, J. M. (2009). An investigation of the effects of corporate ethical values on employee commitment and performance: Examining the moderating role of perceived fairness. Journal of Business Ethics, 89(2), 251-260.

[17] Suib, F. H., \& Said, M. F. (2017). A review of Islamic work ethics and spirituality concepts in service industry. Journal of Nusantara Studies (JONUS), 2(2), 282-294.

[18] Tufail, M., Shahzad, K., Gul, A., \& Khan, K. (2017). The Impact of Challenge and Hindrance Stressors on Job Satisfaction: Moderating Role of Islamic Work Ethics.

[19] Yousef, D. A. (2000). The Islamic work ethic as a mediator of the relationship between locus of control, role conflict and role ambiguity-A study in an Islamic country setting. Journal of managerial psychology, 15(4), 283-298. 